\title{
A case of primary gastric undifferentiated high-grade pleomorphic sarcoma diagnosed with chief complaint of fever: a case report and literature review
}

\author{
Akira Kabashima $^{1 *}$, Koichi Kimura ${ }^{1}$, Kensaku Sanefuji ${ }^{1}$, Satoru Masunari ${ }^{2}$, Seiji Haraoka ${ }^{3}$ and Soichiro Maekawa ${ }^{1}$
}

\begin{abstract}
Background: Undifferentiated high-grade pleomorphic sarcoma in gastrointestinal tract is extremely rare, and its prognosis is poor.

Case presentation: An 82-year-old man visited a previous hospital complaining of fever, general fatigue, and shaking chill, for which he received antibiotics therapy. As the fever continued, he was referred to our hospital, where computed tomography and upper gastrointestinal endoscopy showed a 6-cm gastric tumor. A preoperative biopsy was consistent with a malignant mesenchymal tumor, but could not provide a definitive pathological diagnosis nor prove a cause-andeffect relationship between the chief complaint and the gastric tumor. The gastric tumor had grown to $8 \mathrm{~cm}$ in diameter within a month so we performed a partial gastrectomy. The pathological postoperative diagnosis was undifferentiated high-grade pleomorphic sarcoma that produced granulocyte colony-stimulating factor. The patient's fever quickly improved, and he showed a good postoperative course.
\end{abstract}

Conclusions: We herein report a case of rapidly growing, undifferentiated, high-grade pleomorphic gastric sarcoma, which presented as a chief complaint of fever.

Keywords: Undifferentiated high-grade pleomorphic sarcoma, Stomach, Fever, Granulocyte colony-stimulating factor (G-CSF)

\section{Background}

Undifferentiated high-grade pleomorphic sarcoma (UPS) is a soft-tissue tumor usually found in the limbs and in the retroperitoneum. Its prognosis is poor. Occurrence in gastrointestinal tract is extremely rare. Here, we report a rare case of rapidly growing gastric UPS associated with a persistent fever and discuss the relevant literature.

\section{Case presentation}

An 82-year-old man presented at a nearby hospital with fever, general fatigue, and shaking chill in July 2015. Although he was treated with antibiotics for his high

\footnotetext{
* Correspondence: akaba@munakata-med-hp.gr.jp

'Department of Surgery, Munakata Medical Association Hospital, 5-3-3

Taguma, Munakata, Fukuoka 811-3431, Japan

Full list of author information is available at the end of the article
}

level of c-reactive protein (CRP), his $38-39{ }^{\circ} \mathrm{C}$ fever remained. He was therefore referred to our hospital. When first examined, his body temperature was $38.4{ }^{\circ} \mathrm{C}$ but had normal blood pressure and pulse rate. No abnormal palpable mass was reported. His blood examination findings showed high inflammatory reaction, slightly low coagulability, and mildly activated fibrinolysis. However, we observed no immunoglobulin or specific antibody that could be considered the cause of his fever (Table 1). Abdominal computed tomography (CT) in early August showed a 6-cm tumor in the stomach (Fig. 1a) with an estimated volume of $18.07 \mathrm{ml}$. Neither other tumor nor abscess was observed. Gastrointestinal endoscopy (GIE) in early August showed a 6 - $\mathrm{cm}$ pedunculated oval tumor on the upper part of the greater gastric curvature (Fig. 2). We also found a nearby $2-\mathrm{cm}$ 
Table 1 Patient's clinical data

\begin{tabular}{|c|c|c|c|c|c|}
\hline \multicolumn{2}{|c|}{ Blood count } & \multicolumn{2}{|c|}{ Blood chemistry } & \multicolumn{2}{|l|}{$\begin{array}{l}\text { Immune- } \\
\text { related tests }\end{array}$} \\
\hline$\overline{W B C}$ & $8300 / \mu \mathrm{l}$ & TP & $6.9 \mathrm{~g} / \mathrm{dl}$ & $\lg G$ & $1683 \mathrm{mg} / \mathrm{dl}$ \\
\hline RBC & $384 / \mu l$ & Alb & $3.0 \mathrm{~g} / \mathrm{dl}$ & $\lg A$ & 243 mg/dl \\
\hline $\mathrm{Hb}$ & $10.8 \mathrm{~g} / \mathrm{dl}$ & GOT & $18 \mathrm{U} / \mathrm{I}$ & $\lg M$ & 132 mg/dl \\
\hline $\mathrm{Ht}$ & $35.7 \%$ & GPT & $15 \mathrm{U} / \mathrm{I}$ & Anti SS-A/Ro & $<7.0 \mathrm{U} / \mathrm{ml}$ \\
\hline Plt & $22.5 \times 10^{4} / \mu \mathrm{l}$ & LDH & $139 \mathrm{U} / \mathrm{I}$ & Anti SS-B/La & $<7.0 \mathrm{U} / \mathrm{ml}$ \\
\hline $\begin{array}{l}\text { Clotting } \\
\text { factors }\end{array}$ & & ALP & $279 \mathrm{U} / \mathrm{I}$ & $\beta$-D-glucan & $7.5 \mathrm{pg} / \mathrm{ml}$ \\
\hline PT & $13.1 \mathrm{~s}$ & $\gamma$-GTP & $52 \mathrm{U} / \mathrm{I}$ & MMP-3 & $84.3 \mathrm{ng} / \mathrm{ml}$ \\
\hline PT-INR & 1.23 & BUN & $15.2 \mathrm{mg} / \mathrm{dl}$ & PR3-ANCA & $<1.0 \mathrm{U} / \mathrm{ml}$ \\
\hline Fib & 594.6 mg/dl & $\mathrm{Cr}$ & $0.91 \mathrm{mg} / \mathrm{dl}$ & MPO-ANCA & $<1.0 \mathrm{U} / \mathrm{ml}$ \\
\hline FDP & $6.6 \mu \mathrm{g} / \mathrm{ml}$ & AMY & $60 \mathrm{U} / \mathrm{I}$ & $S \mid L-2 R$ & $411 \mathrm{U} / \mathrm{ml}$ \\
\hline \multirow[t]{4}{*}{ D-dimer } & $1.2 \mu \mathrm{g} / \mathrm{ml}$ & $\mathrm{Fe}$ & $44 \mathrm{mg} / \mathrm{dl}$ & ANA & $<40$ times \\
\hline & & CRP & $11.20 \mathrm{mg} / \mathrm{dl}$ & Anti CCP & $<0.6 \mathrm{U} / \mathrm{ml}$ \\
\hline & & & & Procalcitonin & $0.07 \mathrm{ng} / \mathrm{ml}$ \\
\hline & & & & RF & $<3 \mathrm{IU} / \mathrm{ml}$ \\
\hline
\end{tabular}

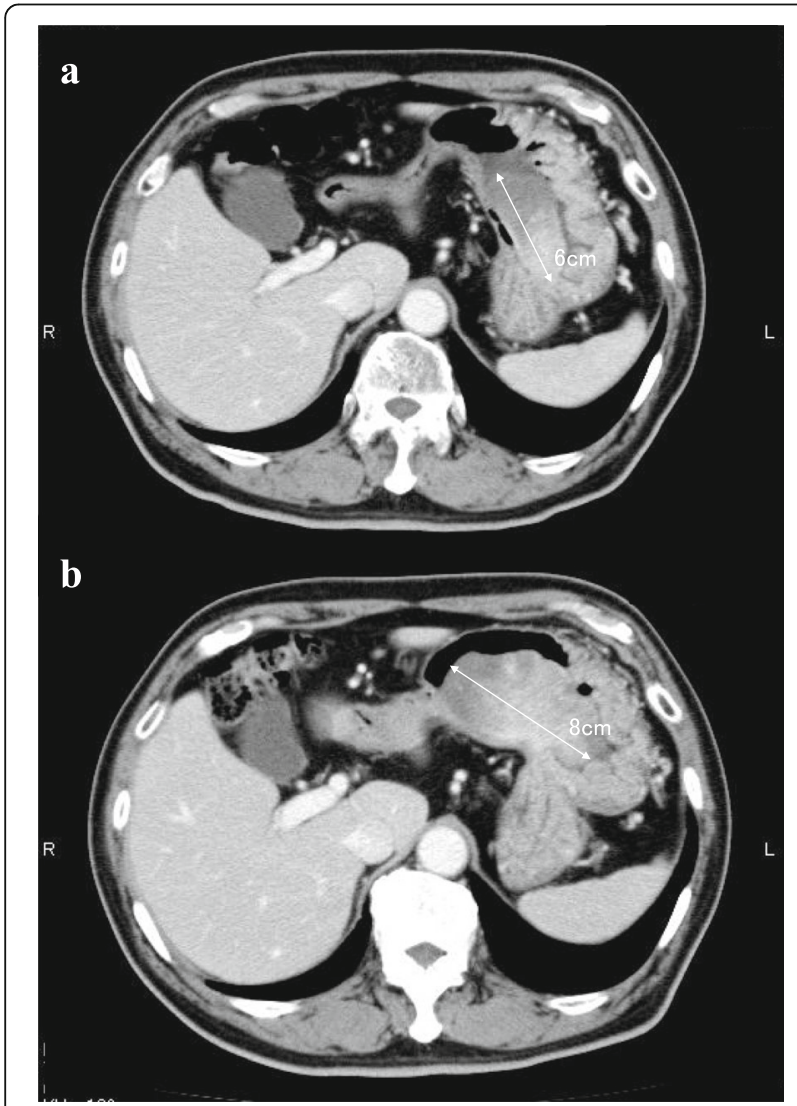

Fig. 1 Abdominal computed tomography (CT) showed a 6-cm gastric tumor in early August (a) that had enlarged to $8 \mathrm{~cm}$ in diameter by early September (b)

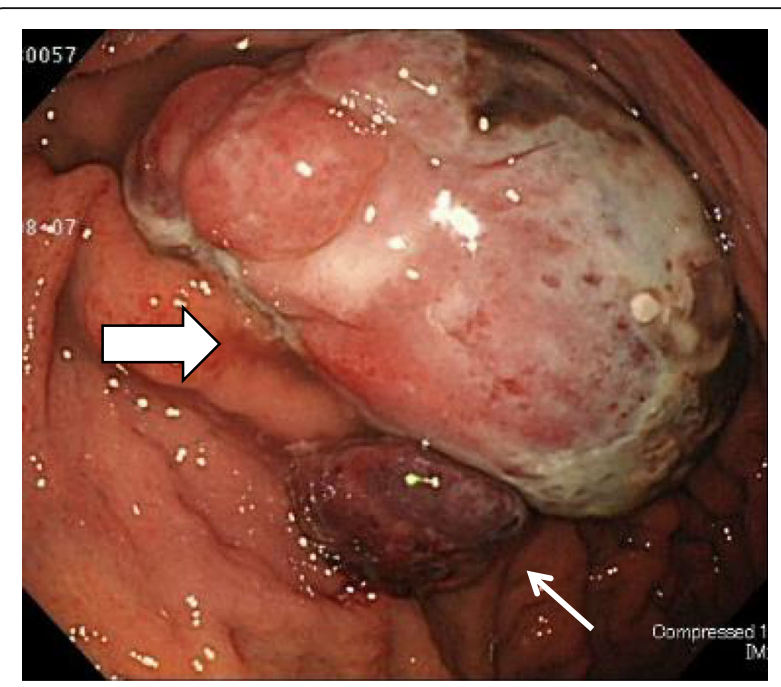

Fig. 2 Gastrointestinal endoscopy in early August showed a 6-cm pedunculated tumor on the greater curvature in the gastric body (thick arrow); nearby, a 2-cm sub-pedunculated tumor was also observed (thin arrow) sub-pedunculated oval tumor. They were elastic-hard, with a smooth surface and a sparse ductal structure.

Biopsy specimen showed the proliferation of atypical cells having pleomorphic or bizarre nuclei. Immunohistochemically, some atypical cells were positive for c-kit, alpha SMA, HHF-35, and calponin, but negative for EMA, cytokeratin (CK) CAM5.2, DOG-1, CD34, caldesmon, and desmin. Although these findings were consistent with malignant mesenchymal tumors, they did not confirm the pathological diagnosis. Upper gastrointestinal fluoroscopy in early August showed a 7-cm, multinodular sub-pedunculated raised lesions with a $12-\mathrm{mm}$ attachment on the upper part of the greater gastric curvature (Fig. 3). The 2-cm tumor observed in the GIE was not visualized. In early September, a CT showed that the gastric tumor had expanded to $8 \mathrm{~cm}$ in diameter within the month, with the volume increased to $53.50 \mathrm{ml}$ (Fig. 1b). The patient's preoperative fever of $38{ }^{\circ} \mathrm{C}$ or higher, which was improved to $36^{\circ} \mathrm{C}$ by taking acetaminophen, occurred once or twice every day. But, he had no symptoms such as abdominal pain and digestive tract obstruction.

We considered that surgery to patients with fever was dangerous, and we could not preoperatively confirm pathological diagnosis of the tumor or its cause-andeffect relationship to the main complaints. But, we finally chose to treat the tumor surgically because we found no lesion that could have caused the fever, and we were concerned that, if delayed, local resection of such a rapidly growing tumor would become impossible.

In mid-September, we performed a partial gastrectomy. We used laparoscopic assistance to disconnect the 

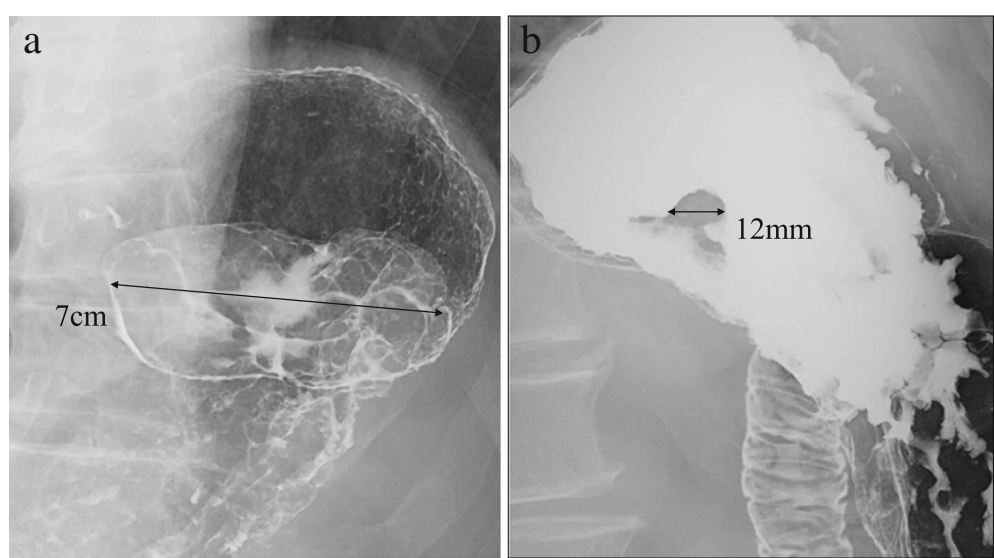

Fig. 3 Upper gastrointestinal fluoroscopy in early August showed a 7-cm sub-pedunculated raised lesion (a) with a 12-mm attachment (b) on the greater curvature of the upper gastric body

omentum from the cardia toward the gastric body to ensure mobility of the stomach. The upper stomach was then lifted out of the abdominal wall through a $6-\mathrm{cm}$ incision in the left upper abdomen. A vertical incision was added from the cardia to the gastric body in the gastric anterior wall, through which both tumors were pulled outside, and their roots excised from stomach wall by automatic suturing devices (Endo-GIA with Tri-Stapler 30-2.5, Covidien), and then closed by Albert-Lembert sutures.

Gross examination showed a pedunculated multinodular polypoid tumor (Fig. 4a) and a polypoid tumor (Fig. 4b), measured about $8 \times 5 \times 3.5$ and $2.2 \times 1.5 \times 1 \mathrm{~cm}$ in size, respectively. Both tumors were solid-elastic consistency, smooth surface, and covered with ulcerated mucosa. The cut surface revealed the gray-white in color with foci of hemorrhage. Microscopically, the resected polypoid tumors were composed of atypical spindle cells and large pleomorphic or bizarre tumor cells arranged in sheets and irregular fascicles, associated with focal hemorrhage and surface ulceration. Mitotic figures (Fig. 5) including abnormal mitoses were frequently encountered (20-25/10 HPF). On immunohistochemical examination, tumor cells were positive for vimentin, $\alpha 1$ antichymotrypsin, CD68, CD163, G-CSF, p53, and Ki-67, some tumor cells were positive for alpha SMA, HHF35, and calponin, but tumor cells were negative for EMA, CK AE1/AE3, CK CAM5.2, c-kit, CD34, DOG1, desmin,
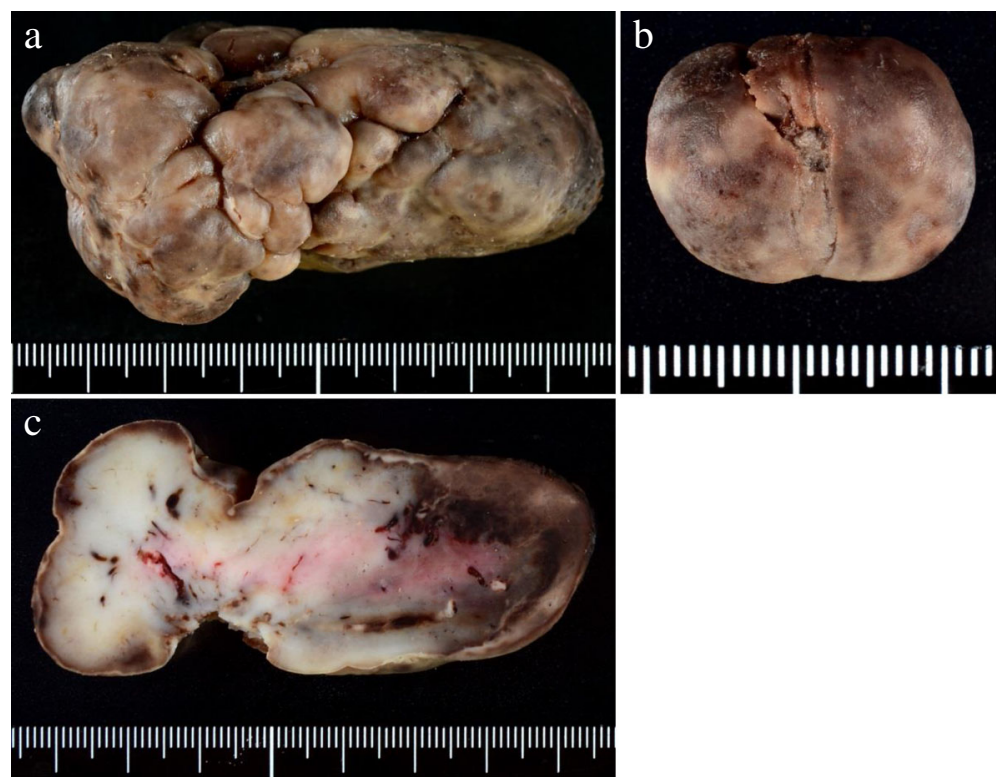

Fig. 4 Gross findings of the tumors showed a pedunculated multinodular tumor (a) and a polypoid tumor (b). A gray-white tumor with focal hemorrhage was observed by cut surface of the large one (c). The tumor was observed very close to the surgical margin 

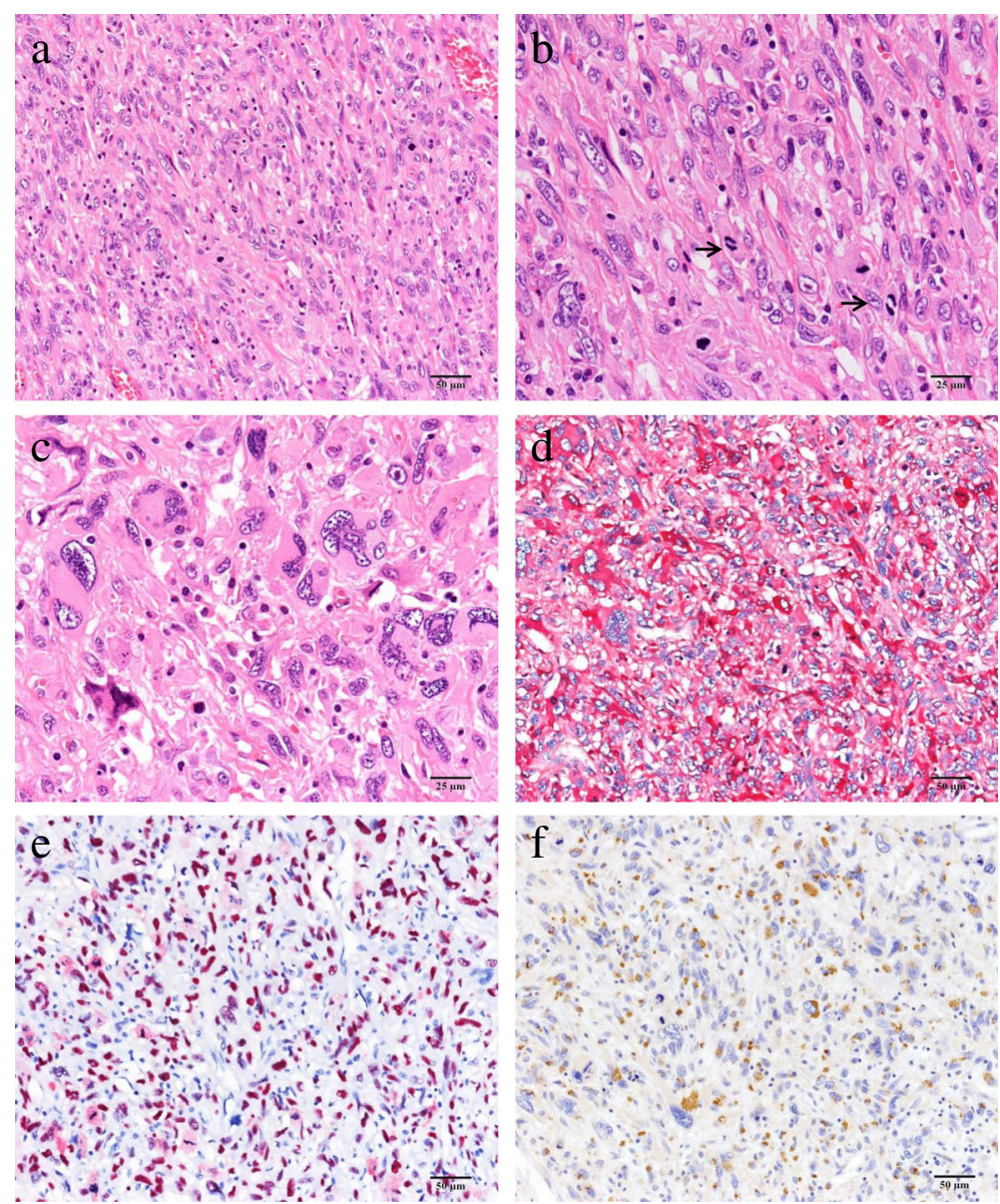

Fig. 5 Microscopic findings showed proliferation of atypical spindle-shaped tumor cells arranged in sheets and irregular fascicles (a). Mitotic figures were frequently encountered (arrows, 20-25/10 HPF) and mild infiltration of lymphoplasmacytoid cells was noted (b). The large pleomorphic and bizarre tumor cells were also observed (c). Immunohistochemically, the tumor cells were positive for a1-antichymotrypsin (d), p-53 (e), and G-CSF (f)

caldesmon, S-100 protein, synaptophysin, hCG, HMB45, myoglobin, and CD30. The histologic and immunohistochemical features were consistent with undifferentiated high-grade pleomorphic sarcoma (pleomorphic malignant fibrous histiocytoma, UPS) producing granulocyte colony-stimulating factor (G-CSF).

Although the patient had a $38{ }^{\circ} \mathrm{C}$ fever twice on 1-2 postoperative days (POD), no fever or other complications were observed thereafter. He began taking meals on 5POD, and he was discharged with satisfactory progress on 12POD. Positron emission tomography (PET)/ CT examination on 1 month after surgery showed accumulated fluoro-2-deoxy-D-glucose at the wound, but no other abnormal accumulation.

\section{Discussion}

Malignant fibrous histiocytoma (MFH) has been classified into three subtypes: pleomorphic, inflammatory, and giant cell. By the World Health Organization (WHO) classification of bone and soft-tissue tumors of 2002, pleomorphic-type MFH was defined as a synonym for UPS [1]. Typically, UPS forms a large, rapidly growing solid mass and is histologically characterized by pleomorphic tumor cells in storiform patterns. UPS does not tend to show clear differentiation and has no specific immunohistological marker [1, 2]. Although UPS was defined in 2002, its epidemiology and prognosis has obscured because of its rarity. In reports of MFH, it commonly occurs in men and those older than 40 years, with a frequency of $1-2$ cases per 100,000 people [3].MFH has been reported in limbs (68\%), abdominal cavity/retroperitoneum (16\%), trunk (9\%), head and neck (3\%), or gastrointestinal tract (4\%). Its prognosis is poor, with a repoted 2 -year survival rate of $60 \%$, and a 5 -year survival rate of $47 \%$ [3].

Primary gastric UPS or MFH is quite rare. Saito et al. reported 16 case reports of primary UPS or MFH of stomach, including one they reported and 14 found in PubMed using the keywords "undifferentiated pleomorphic sarcoma" and "malignant fibrous histiocytoma" 
during 1984-2011 [4-16]. The data of 16 cases and this case are summarized in Table 2. The average age was about 61 years old (range: 17-82 years old). Average diameter was $6.7 \mathrm{~cm}$ (range: $1-15 \mathrm{~cm}$ ). Seven of the 16 patients showed invasion or metastasis and had died by the time they were reported. Only 4 of the 16 patients were 2-year survivors at the time they were reported. No 5 -year survivors were yet reported. UPS is considered to have worse prognosis than other forms of MFH. In addition, there has been no report about gastric UPS producing G-CSF.

According to the National Comprehensive Cancer Network (NCCN) Soft Tissue Sarcoma Guidelines, surgical resection with sufficient margin is the first-choice treatment for UPS. Amputation is required for tumors in limbs, so various surgical methods have been used with the aim of preserving function [17]. The first choice for resectable sarcomas in the inner trunk is considered to be en bloc excisions with $\geq 1$-cm margins. Additional resection is recommended for margins narrower than $1 \mathrm{~cm}$. As lymphatic metastasis is rare, systematic lymph node resection is not required. If hepatic metastases or infiltrations to nearby organs are resectable, their complete resection is desirable. Chemotherapy, radiation therapy, or hyperthermia have been used for unresectable tumors. The combination of cisplatin, ifosfamide, and adriamycin for reducing metastasis has been reported [18]. However, chemotherapy, radiation therapy, and hyperthermia have not led to satisfactory results $[19,20]$.

At first we suspected that infection or autoimmune diseases could have caused the fever and high CRP level; we had doubts about their association with the gastric tumor. However, as the fever and CRP level dramatically improved after the surgery, the gastric tumors were clearly related to the main complaints. There are reports about cases of UPS and MFH presenting initially with fever [21-23], and reports about cases of MFH producing actively cytokines such as G-CSF [24-27]. But. this is the first report about gastric UPS with fever and rapid growth due to producing G-CSF. G-CSF is thought to cause paraneoplastic syndrome such as fever or increased CRP, and cytokines such as G-CSF have been suggested as markers for UPS. In this case, we should reflect that treatment was delayed because we could not understand that these symptoms could be a clue to the diagnosis.

\section{Conclusions}

We found a rare case of gastric UPS. As UPS is a rapidly growing, frequently recurring tumor, its prognosis is poor. Patients require strict postoperative observation.

Table 2 Summarization in 16 cases diagnosed primary gastric UPS and MFH

\begin{tabular}{|c|c|c|c|c|c|c|c|c|c|c|c|}
\hline No. & Year & Author & Age & Gender & $\begin{array}{l}\text { Chief } \\
\text { complaint }\end{array}$ & Site & Macroscopic forms & Size $(\mathrm{cm})$ & $\begin{array}{l}\text { Metastasis or } \\
\text { invasion }\end{array}$ & Therapy & Outcome \\
\hline 1 & 1984 & Morita & 60 & $\mathrm{~F}$ & Pain & Antrum & SMT & 3.5 & Gall bladder & $\begin{array}{l}\text { Operation, } \\
\text { hemotherapy }\end{array}$ & Death, 6POM \\
\hline 2 & 1985 & Shibuya & 60 & M & Bleeding & Antrum & Raised type & 4.5 & Ileum & Operation & Death, 3POM \\
\hline 3 & 1985 & Randner & 77 & $\mathrm{~F}$ & Pain & Body & SMT & 1 & Liver & None & Death \\
\hline 4 & 1988 & Wright & 42 & $M$ & Bleeding & Cardia & Ulcerative type & 5 & Lung & $\begin{array}{l}\text { Operation, } \\
\text { chemotherapy }\end{array}$ & Death, 17POM \\
\hline 5 & 1989 & Ranthakrishman & 51 & $M$ & Pain & Antrum & Tube-occupied type & Huge & None & $\begin{array}{l}\text { Operation } \\
\text { (stoma) }\end{array}$ & Death, 0.5POM \\
\hline 6 & 1998 & Takagi & 64 & $\mathrm{~T}$ & Amenia & Body & SMT & 7.5 & None & Operation & Alive, 6POM \\
\hline 7 & 1998 & Wada & 78 & M & Pain & Body & Ulcerative type & 5 & None & Operation & Alive, 24POM \\
\hline 8 & 1998 & Wada & 77 & M & Pain & Body & Ulcerative type & 4 & Lung & Operation & Death, 48POM \\
\hline 9 & 1998 & Wierseme & 37 & $\mathrm{~F}$ & Amenia & Body & Ulcerative type & 5 & None & Operation & Alive, 38POM \\
\hline 10 & 2000 & Nakai & 57 & $M$ & Pain & Antrum & Tube-occupied type & 5 & Liver & $\begin{array}{l}\text { Operation, } \\
\text { chemotherapy }\end{array}$ & Death, 7POM \\
\hline 11 & 2003 & Accattatis & 17 & $\mathrm{~F}$ & Pain & Body & Unknown & 15 & None & Operation & Death, 0.5POM \\
\hline 12 & 2006 & Shinnshi & 54 & $M$ & Pain & Antrum & SMT & 4 & None & Operation & Alive, 36POM \\
\hline 13 & 2007 & Agaimy & 79 & M & None & Cardia & Ulcerative type & 8 & None & Operation & Death, 0.5POM \\
\hline 14 & 2007 & Agaimy & 68 & $\mathrm{~F}$ & Weight loss & Body & $\begin{array}{l}\text { Extraluminal growth } \\
\text { type }\end{array}$ & 12 & None & Operation & Alive, 6POM \\
\hline 15 & 2013 & Kinoshita & 74 & $\mathrm{~F}$ & Pain & body & Raised type & 13 & Liver & Chemotherapy & Death \\
\hline 16 & 2016 & This case & 82 & M & Fever & Body & Raised type & 8 & None & Operation & Alive \\
\hline
\end{tabular}




\section{Abbreviations}

(PET)GIST: Gastrointestinal stromal tumor; CRP: C-reactive protein: CT: Computed tomography; G-CSF: Granulocyte colony-stimulating factor; GIE: Gastrointestinal endoscopy; MFH: Malignant fibrous histiocytoma; NCCN: National Comprehensive Cancer Network; PET: Positron emission tomography; UPS: Undifferentiated high-grade pleomorphic sarcoma; WHO: World Health Organization

\section{Authors' contributions}

AK drafted the manuscript. SM performed the preoperative examination. AK, $\mathrm{KK}, \mathrm{KS}$, and SM performed the operation. SH participated in the pathological examination. All authors read and approved the final manuscript.

\section{Competing interests}

The authors declare that they have no competing interests.

\section{Consent for publication}

Written informed consent was obtained from the families of the patient for publication of this case report and accompanying images.

\section{Publisher's Note}

Springer Nature remains neutral with regard to jurisdictional claims in published maps and institutional affiliations.

\section{Author details}

'Department of Surgery, Munakata Medical Association Hospital, 5-3-3 Taguma, Munakata, Fukuoka 811-3431, Japan. Department of Radiology, Munakata Medical Association Hospital, 5-3-3 Taguma, Munakata, Fukuoka 811-3431, Japan. ${ }^{3}$ Department of Pathology, Fukuoka University Chikushi Hospital, Chikushino, Fukuoka 818-0067, Japan.

Received: 16 December 2016 Accepted: 2 March 2017

Published online: 08 March 2017

\section{References}

1. Fletcher CDM, Unni KK, Mertens F, editors. World health organization classification of tumors: pathology and genetics of tumors of soft tissue and bone. Lyon: IARC Press; 2002.

2. Hashimoto Y. New WHO classification of tumors: tumors of soft tissue. Pathol Clin Med. 2004;22:113-26.

3. Weiss SW, Enzinger FM. Malignant fibrous histiocytoma: an analysis of 200 cases. Cancer. 1978;41:2250-66

4. Satou M, Oikawa K, Uchiyama S, Inomata Y, Abe O, Sasano K. A case of undifferentiated pleomorphic sarcoma of the stomach showing rapid growth [in Japanese]. Nihon Shokakibyo Gakkai Zasshi. 2013;110:1272-80.

5. Radner H, Beham A, Weybora W. Malignant fibrous histiocytoma of stomach. A case report with a review of the literature. Pathology. 1985;6:313-8.

6. Morita T, Kato T, Furukawa K, Ito Y. A case report of malignant fibrous histiocytoma in regions of stomach and gall bladder. J Jpn Clin Cytol. 1984;23:425-9.

7. Shibuya H, Azumi N, Ono Y, Abe Y. Multiple primary malignant fibrous histiocytoma of stomach and small intestine. Acta Pathol Jpn. 1985;35:157-64.

8. Wright Jr JD, Kyriakos M, Deschryver-Kecskemeti K. Malignant fibrous histiocytoma of stomach. A report and review of malignant fibrohistiocytic tumors of the alimentary tract. Arch Pathol Lab Med. 1988;12:251-8.

9. Ranthakrishnan V, Arianayagam S, Kumar G. Primary malignant fibrous histiocytoma of stomach:(a case report). Australas Radiol. 1989;33:302-4.

10. Takagi K, Iwakiri K, Matsunaga H. Malignant fibrous histiocytoma (MFH) of the stomach, report of a case [in Japanese]. Stomach Intestine. 1998;33:1769-75.

11. Wada Y, Matsushita T, Sarumaru S, Ryo J, Isobe H, Satoh B, et al. Malignant fibrous histiocytoma of stomach: report of two cases. Surg Today. 1998;28:296-300.

12. Wiersema AM, Wobbes T, Pruszczynski M, Sluis RF. Malignant fibrous histiocytoma of stomach during pregnancy: a case report. Eur J Obstet Gynecol Reprod Biol. 1998;80:71-3.

13. Nakai S, Morita T, Utida Y, Sasaki Y, Kumano S, Watanabe S, et al. A case of primary malignant fibrous histiocytoma of the stomach [in Japanese]. Nihon Shokakibyo Gakkai Zasshi. 2000;97:337-41.

14. Accattatis V, Venetucci $P$, Zeppa P, Radice L. Malignant fibrous histiocytoma of the stomach. Radiol Med. 2003;106:481-5.

15. Shinji A, Mukawa K, Okiyama W, Okiyama Y, Hara H, Tamura Y, et al. A case of malignant fibrous histiocytoma of the stomach [In Japanese]. Endosc Forum Dig Dis. 2006;22:12-6.
16. Agaimy A, Gaumann A, Schroeder J, et al. Primary and metastatic highgrade pleomorphic sarcoma/malignant fibrous histiocytoma of the gastrointestinal tract: an approach to the differential diagnosis in a series of five cases with emphasis on myofibroblastic differentiation. Virchows Arch. 2007:451:949-57.

17. NCCN Guidelines for Patients. Soft Tissue Sarcoma. Version 1.2014. Available from: https://www.nccn.org/patients/guidelines/sarcoma. Accessed 12 Apr 2016.

18. Fujita A, Isai T, Kondou M, Minase S, Tgaki S, Sekine K. A case of malignant fibrous histiocytoma of jejuna origin with marked response to cisplatin, ifosfamide and adriamycin. Jpn J Cancer Chemother. 1993;20:2053-6.

19. Takahashi K, Tanaka H, Itoh N, Iwasaki K, Suzuki R. Experience of radiation therapy for malignant fibrous histiocytoma [in Japanese]. Orthop Traumatol. 1983;31:658-63

20. Yokouchi M, Arishima Y, Yamasaki K, Hamada H, Kawamura K, Fujimoto Y, et al. Radio-hyperthermo-chemotherapy for soft tissue sarcoma: short-term results. Orthop Traumatol. 2007;56:640-2.

21. Katsourakis A, Noussios G, Hadjis I, Evangelou E, Chatzitheoklitos E. Primary malignant fibrous histiocytoma: A rare case. Case Rep Med. 2011. doi: 10. 1155/2011/13480

22. Pathrose G, John TN, Manojkumar R. A rare case of malignant fibrous histiocytoma/Pleomorphic undifferentiated sarcoma of the kidney. J Clin Diagn Res. 2015;9:27-9.

23. Li YR, Akbari E, Tretiakova MS, Hart J, Akbari M, Urbanski SJ, et al. Primary hepatic malignant fibrous histiocytoma: clinicopathologic characteristics and prognostic value of ezrin expression. Am J Surg Pathol. 2008:32:1144-58.

24. Kato T, Kojima T, Shimizu T, Sasaki H, Abe M, Okushiba S, et al. Inflammatory malignant fibrous histiocytoma of the gallbladder: report of a case. Surg Today. 2002;2:81-5.

25. Reinecke P, Moll R, Hildebrandt B, Schmitz M, Schneider EM, Koldovsky P, et al. A novel human malignant fibrous histiocytoma cell line of the heart $(\mathrm{MFH}-\mathrm{H})$ with secretion of hematopoietic growth factors. Anticancer Res. 1999:19:1901-7.

26. Yoshida M, Matsuzaki H, Hata H, Matsuno F, Takeya M, Okabe H, et al. Neutrophil chemotactic factors produced by malignant fibrous histiocytoma cell lines. Br J Cancer. 1993;67:508-13.

27. Muyumi E, Okuno T, Ogawa T, Kurata K, Ishioka H, Hamamoto $\mathrm{H}$, et al. Malignant fibrous histiocytoma of soft tissue producing granulocyte colonystimulating factor. Intern Med. 2001:40:536-40.

\section{Submit your manuscript to a SpringerOpen ${ }^{\circ}$ journal and benefit from:}

- Convenient online submission

- Rigorous peer review

- Immediate publication on acceptance

- Open access: articles freely available online

- High visibility within the field

- Retaining the copyright to your article

Submit your next manuscript at $\boldsymbol{s p r i n g e r o p e n . c o m ~}$ 